\title{
La Iglesia, símbolo profético pascual del reinado en la historia
}

\section{Víctor Codina,}

Bolivia.

\section{La Iglesia, ¿una institución meramente funcional?}

A lo largo de la historia siempre ha surgido la pregunta "¿para qué sirve la Iglesia?". Las respuestas han sido variadas según el momento y los intereses de grupo: para bendecir el imperio romano o el sistema político de turno, para defender la moral y educar a los jóvenes en las buenas costumbres, para "salvar las aimas", para predicar el evangelio y administrar los sacramentos, para ayudar a los pobres, para cuidar enfermos y desvalidos, para fomentar la cultura, para colaborar al desartollo de los pueblos, para hacer la revolución, para dar un aura de sacralidad ritual a los momentos límites de la existencia humana, etc.

En este caso, la Iglesia es analizada desde la razón instrumental, y aparece claramente como una institución funcional especializada en la religión, una expendeduría de servicios religiosos, visible, concreta y eficiente, con fuerte peso social y político, con una buena organización, bien lubricada, poseedora de una doctrina clara y definida, con una praxis moral correcta.

Y lógicamente, en esta concepción, todos los grupos y elementos de la Iglesia participan del carácter práctico e instrumental de la institución y se apropian de la institución para su interés.

La jerarqufa, a cuya cabeza está el papa, en esta concepción instrumental se convierte en el centro y el vértice de la institución, se identifica con la Iglesia. La Iglesia es el papa. Algunas afirmaciones grandilocuentes del papa Pío IX ("Yo soy el camino, la verdad y la vida") reflejan esta óptica.

Los ministros sagrados, en esta clave de reflexión, son los hombres de los sacramentos, porque los sacramentos son los instrumentos más eficaces para comunicar al pueblo la gracia de Dios (ex opere operato). En expresión catequética, los sacramentos son los siete canales de gracia que manan de la fuente de agua viva que es la Iglesia. Y los sacerdotes son quienes tienen la 
llave de estos caños de gracia.

Por esto, en la sacramentología clásica se insiste mucho en la importancia de la validez y licitud de los sacramentos en orden a su eficacia, dejando al margen las dimensiones más simbólicas y comunitarias.

Por ejemplo, los teólogos escolásticos se plantean cuestiones tales como si un sacerdote puede consagrar toda una panadería y todo el vino de una bodega, si pronuncia las palabras rituales de la consagración. Santo Tomás cree que esta consagración es válida, aunque peque el sacerdote al hacerlo', mientras que Y. Congar opina que, en este contexto, no existe consagración.

Por este mismo motivo preocupó siempre el tema de la validez de los sacramentos administrados por grupos disidentes o en pecado: la cuestión de los rebautizanles que enfrentó a Cipriano de Cartago con el papa Esteban de Roma, la polémica de Agustín con los donatistas, la cuestión de la validez de las órdenes anglicanas en tiempos de León XIII o de las exıravagantes ordenaciones del Palmar de Troya...

La vida religiosa también aparece, desde esta perspectiva de la razón instrumental, como un medio eficaz suscilado por el Espíritu para responder a situaciones nuevas y urgentes de la Iglesia y de la sociedad: pobres, enfermos, niños abandonados, educación, misiones, promoción y desarrollo. Por otra parte se la considera como un estado de perfección, con una superioridad casi ontológica sobre el resto de los fieles.

Dentro de esta concepción funcional de la Iglesia, la vida religiosa apostólica activa es la que realiza más claramente su función utilitaria, por encima de la vida monástica y contemplativa, que en occidente ha quedado siempre más marginada.

Tampoco es casual que, desde esta mentalidad funcional, la vida religiosa, originariamente laical, haya ido introduciendo el sacerdocio entre sus miembros y se haya ido clericalizando, hasta desembocar actualmente en una creciente "parroquialización" de la vida religiosa (en expresión de J. B. Metz) para suplir la carencia de clero diocesano. En todo este proceso se ha ido dando una mayor valoración de la vida religiosa clerical por encima de la laical y, consiguientemente, de la vida religiosa masculina por encima de la femenina. Detrás de la actual problemática del sacerdocio de la mujer religiosa, además de la cuestión femenina, seguramente se esconde una visión funcional y clerical de la vida religiosa: as! las religiosas podrían ser más "útiles" pastoralmente...

Los laicos son vistos como un medio para hacer presente la Iglesia en la sociedad secular y transformarla a la luz del evangelio. Son como el brazo

I. III. q. 74 a 2 , sed contra y ad 2 . 
secular de la Iglesia, un instrumento de la jerarquía para llegar a donde ésta no puede llegar. Son como tropas de choque que están en la vanguardia de la lucha.

En el mundo laical, el sacramento del matrimonio es visto también desde una clave funcional: un medio providencial y santificado por la gracia, para usar la sexualidad correctamente y procrear hijos. Es un contrato jurídico con deberes y obligaciones (reddere debitum). La célebre discusión sobre los fines del matrimonio es heredera de esta mentalidad instrumental: ¿para qué sirve el matrimonio? ¿Para ayudar a los esposos, para remediar la concupiscencia o para engendrar hijos?

Esta visión predominantemente utilitaria y eticista de la Iglesia es común tanto a grupos de derechas (que insisten en la dimensión de la ética individual, de la moral sexual y familiar, en "salvar el alma"...) como a sectores de izquierda (que acentúan el papel de la institución eclesial en la élica social, la reforma estructural, la liberación, o incluso como plataforma revolucionaria).

Esta visión presupone la relevancia de la dimensión doctrinal en la Iglesia (por ejemplo, la importancia de la unidad doctrinal y del magisterio), de la práctica eclesial (importancia de la moral, de la praxis sacramental) y para poderse llevar a cabo necesita un gobierno bien organizado y uniforme, centralizado y dotado de un buen aparato jurídico y económico. Cualquier discrepancia o "disenso" rompe la unidad monolítica del aparato eclesial.

Dentro de esta visión organizativa, lógicamente hay diferentes niveles y estamentos eclesiales: la virginidad es más perfecta que el matrimonio (DS 1810), la vida consagrada y la sacerdolal es superior a la vida laical. Delrás de esta jerarquización existe una visión dualista de la vida cristiana: el mundo sagrado, más perfecto por estar unido a Dios, corresponde a clérigos y religiosos, mientras que el mundo profano o secular, más bajo e imperfecto, queda relegado a los laicos. Cuando un sacerdote abandona su ministerio, es "reducido" al estado laical.

Esta concepción institucional y funcional de la Iglesia, sin duda, contiene elementos válidos: la Iglesia participa de la visibilidad histórica y encarnatoria de Jesús, tiene corporalidad y necesita leyes sociales como en todas las instituciones humanas: derecho, organización, administración, amplios fondos económicos, centros rectores, canales de comunicación, respresentantes públicos, etc.

Pero esta concepción teológica, si no se contrapesa con otros elementos, se agota en un moralismo utilitarista y deja de responder a temas importantes no inmediatamente pragmáticos ni funcionales como la vivencia de la comunidad, la experiencia personal de Dios, el testimonio, la gratuidad, el placer y la fiesta, la contemplación, el fracaso y la cruz, el ministerio y la libertad dinámica del Espíitu.

La razón ilustrada, teórica y práctica, es cuantitativa y unidimensional, incapaz de penetrar en la dimensión más prolunda de la realidad, que es misteriosa. E incluso cuando este lipo de razón ilustrada e instrumental se aplica a las 
realidades prolundas de la fe, afecta a su mismo contenido, pues el medio es ya mensaje.

En esta óplica, lácilmente, la misión de la Iglesia queda reducida al campo de lo cuantitativo y numérico (¿quiénes son miembros de la Iglesia?, ¿cuántos son los bautizados?, ¿cuántos sacramentos son distribuidos?, ¿quién es más perfecto?). El progreso eclesial sc concibe al modo del desartollo lécnico, como una evolución geográlica y especial, sin rupturas ni transformaciones. El tiempo eclesial también es uniforme, sin atender a momentos más densos de presencia salvífica (la "hora: joánica de Jesús, el kairós paulino, los signos de los tiempos).

Una consecuencia de todo ello es que hoy día muchos, sobre todo entre las nuevas generaciones modernas y postmodernas, se alejan cada vez más de las instituciones religiesas y también de la Iglesia, se sienten cada día menos urgidos por sus leyes, más libres frente a algunos de sus dogmas, cada día más ajenos a su magisterio moral (sea en moral sexual o en moral social), y ante una situación de vacío religioso van a buscar experiencias religiosas y sagradas al margen de la institución religiosa oficial eclesial (religiones civiles y profanas, nuevos misticismos y esoterismos, nuevos movimientos religiosos...).

Ante esta situación de desinstilucionalización de las religiones históricas y de desintegración de los sistemas de creencia, se comprende la actual estrategia de la Iglesia de querer fortalecer los elementos de cohesión doctrinal y moral, para crear la identidad y reforzar lo institucional. Las masivas peregrinaciones de jóvenes a lugares históricos y estratégicos como Roma, Santiago, Czestochowa, los viajes de Juan Pablo II, el nuevo catecismo universal, las grandes celebraciones anunciadas para el tercer milenio, tienen sin duda este objetivo. Pero aun en estos casos, donde se utilizan ambiguamente algunos símbolos poderosos al servicio de la institución, no hay correspondencia entre la masiva aceptación de un fenómeno religioso espectacular (un viaje papal o el catecismo universal) y la adhesión a su mensaje. La razón instrumental es capaz de devorar incluso los símbolos.2

Pero ¿esta es la imagen de Iglesia que surge del Nuevo Testamento y de la tradicion primitiva?

\section{El reino de Dios: ¿instrumento o símbolo?}

Es un dato hoy adquirido tanto por la exégesis bíblica como por la cristologla sistemática que el inicio y el centro de la predicación de Jesús no lo constiluye la Iglesia, sino el reino de Dios (Mc 1, 15; Mt 3, 17; Lc 4, 43). Por esto, antes de hablar de la Iglesia hemos de centrarnos en el reino de Dios.

2. Remito a las finas observaciones de J.M. Mardones. Para comprender las nuevas formas de religión, Estella, 1994, p. 63. 
Pero Jesús no define el concepto de reino, sino que, partiendo de la experiencia de Israel, lo describe con imágenes. El reino de Dios es una realidad misteriosa: la soberanía absoluta de Dios, su reinado en el pueblo, su proyecto salvífico. Como toda realidad profunda y última, el reino sólo puede ser sugerido de forma simbólica.

Israel vivió esta soberanía de Yahvé estrechamente ligada a diversas experiencias histórico-salvíficas: el éxodo, como gesta liberadora de Yahvé de la opresión de Egipto; la creación, como experiencia del señorío de Dios sobre todos los pueblos y sobre la misma naturaleza; la monarqula, como imagen mesiánica de la soberanía de Dios; los anuncios escatológicos de los profetas que anuncian la utopía de un reino de justicia y de paz a favor de su pueblo.

Son sobre todo los profetas quienes presentan de forma utópica y simbólica este reinado de Dios: lanzas convertidas en arados (Is 2,4 ), el niño jugando con la serpiente, el cordero con el lobo (Is 11), árboles siempre fecundos regados por un río exuberante de vida ( $\mathrm{Ez} 47$ ), desposorios de Dios con la virgen de Israel (Is 61, 10), lierra nueva y cielo nuevo, sin mar ni llantos (Apoc 21). Y los profetas realizan acciones simbólicas (ôt) que tienen la virtualidad de hacer presente de forma anticipada el proyecto de Dios sobre su pueblo: la división del reino, el destierro, el retorno a Palestina, la vida y abundancia del reino futuro $(1 \operatorname{Re} 11$, 29-33; Ez 4-5; Ez 12, 1-20; Jer 18, 1-12; Jer 19). El reino (uturo comienza ya de forma simbólica en la historia presente. Muchas veces la vida del mismo profeta es un símbolo del reino de Dios para el pueblo (Os 2-3; Is 20; Ez 4; Jer 16 y 36).

En esta visión profética el reino es el horizonte último donde se enmarca toda la historia de salvación. Este horizonte se expresa a través de una metáfora, de matriz sociopolítica: la soberanía del rey sobre su pueblo. En el caso del reinado de Dios, lo importante es constatar la soberanía de Dios, su reinado. Este símbolo es integral, ya que une los diversos momentos de la realidad: el pasado, el presente y el futuro, lo interior y lo exterior, la historia y la escatología.

Cuando Jesús entra en nuestra historia se encuentra, dentro del mundo judio, con una serie de corrientes diferentes en torno al concepto e interpretación del reino, todas ellas con grandes implicaciones sociales. El concepto simbólico del reino se transforma muchas veces en un mero instrumento al servicio de intereses de grupo: entonces el reino deja de ser un horizonte utópico y se convierte en una institución, en una simple mediación instrumental, en una apropiación partidista.

1. Unos esperan el reino de un mesías davídico, triunfador bélico de los enemigos de Israel, que los liberará del yugo del imperio romano, de forma violenta y por la lucha armada (sicarios o zelotes). Dentro de esta misma perspectiva, algunos grupos del judaísmo tardío, como aparece sobre todo en los deuterocanónicos, se dejan llevar por imágenes apocalípticas, que anuncian la 
destrucción de este mundo por medio de desastres cósmicos y la aparición de un nuevo eón, que inaugura la victoria final de Yahvé.

2. Otros grupos esperan un reino meramente interior, por eso huyen del mundo (esenios) o se esfuerzan en el exacto cumplimiento de la ley (fariseos). Esperan pacíficamente un reino para los que se hayan purificado y cumplido fielmente la ley.

3. Otros, como los saduceos y sacerdotes, indentifican el reino de Dios con la teocracia religiosa y sacerdotal de Israel, de la que ellos son representantes: buscan aprovecharse de la ambigua situación sociopolítica de Israel en el imperio romano y no quieren que las cosas cambien.

Estos grupos han hecho del reino no una lectura simbólica, sino parcial, partidista, unidimensional, reduccionista, dividiendo y separando los aspectos inseparables del reino de Dios. El reino se convierte en una institución, política, legalista, sacerdotal, judía, antirromana, económica.

4. Por esto Jesús habla, ciertamente, del reino de Dios para anunciar su buena noticia, pero se refiere a él como un símbolo, no como un instrumento.

Se aparta del legalismo fariseo, al que critica su hipocresía; no se alinea con el espiritualismo esenio, sino que llama a los pecadores a su mesa; no acepta el tremendismo apocalíptico y violento de los que desean hacer llover fuego del cielo, ni las posturas de un mesianismo triunfalista y de poder, sino que se sitúa en la línea del Siervo de Yahvé; ni aprueba el pragmatismo materialisla saduceo, como aparece en la expulsión de los mercaderes del templo y sus críticas al poder. No acepta un visión parcial, desintegradora y "diabólica" del reino.

Jesús se inscribe en la línea profética: el reino de Dios es un símbolo, que significa un promesa utópica y comunitaria para el pueblo que sufre, pero esta promesa comienza ya ahora a hacerse realidad con su venida. El reino no se define, se narra a través de imágenes: red, tesoro, perla, grano de mostaza, levadura, banquete de bodas, vino nuevo, fuego... Sus milagros y exorcismos, el comer con los pecadores y perdonar pecados, el lavar los pies a sus discípulos o el celebrar la última cena pascual, son acciones simmbólicas, en continuidad con las acciones proféticas ( $\hat{o} t)$, que muestran la integralidad y la eficacia del reino. El reino se muestra en la práctica

Estos gestos simbólicos y proféticos de Jesús no son neutros ni uniformes, sino que se realizan prioritariamente con los pobres, que son quienes sufren la injusticia, para indicar que éstos son los primeros destinatarios del reino de Dios y que el reino de Dios será la respuesta a las necesidades reales y concretas del pueblo pobre, como símbolo y comienzo de una utopra, cuya plenitud será escatológica.

Y esta opción prioritaria y real por los pobres es la expresión simbólica del 


\section{LA IGLESIA, SIMBolo PROFetico PA $\{$ CUy}

rostro misericordioso del Padre, el Abba de Jesús, que se conmueve ante-ál sufrimiento injusto de sus hijos y desea crear una verdadera fraternidad humana.

Por esto, estas señales proféticas de Jesús son señal de que el reino ya está en medio de Israel, de que existe una presencia viva y dinámica del reino ( $\mathrm{Lc} 7$, $22 ; 11,20)$. El mismo Jesús es un signo del reino, el gran signo ligado al signo de Jonás, es decir, a su muerte y resurrección.

Desde esta óptica profética del ya - sí pero todavía- no, se entienden las parábolas "vegetales" del reino: el reino es un germen, una pequeña semilla, un poco de levadura (Mc 4, 26-33; MI 13, 33). Esta presencia germinal del reino llegará un día a su plenitud. El reino de Dios ha comenzado ya y se manifiesta como salud para los enfermos, perdón para los pecadores, luz para los ciegos, abundancia para los hambrientos, liberación de los espíritus malignos, valoración de las mujeres, vida para los muertos, en fin, buena noticia para los pobres (MI 5, 3-12; Lc 6, 20-26; Mı 11, 5; Lc 4, 18; 7, 22).

Pero las expectativas de que el reino se implante y triunfe con Jesús fracasan, contrariando seguramente las primeras expectativas del mismo Jesús. Jesús es llevado a la cruz, sus discípulos se dispersan, todo su proyecto se hunde en la noche del abismo. Lo matan los que no aceptan su visión simbólica del reino y están decepcionados de su intregralidad profética: los sacerdotes y fariseos que se escandalizan de su crítica al templo y a la religión establecida de Israel, los zelotes y revolucionarios políticos (¿Judas? ¿Barrabás? ¿Los dos ladrones crucificados con él?), que se decepcionan y se hartan de su paciencia con Rorna y de que Jesús no empuñe las armas. Pilato y Herodes no se interesan tampoco por su reino y, en el fondo, lo temen. Jesús es entregado a la muerte por un problema de hermeneútica en la interpretación del concepto de reino...

La resurrección es la respuesta del Padre a la visión del reino de Jesús: Jesús tenía razón, el reino de Dios es englobante y simbólico, comienza humildemente y sólo llegará a su plenitud en la escatología final. Es un reino que comienza ya aquí y ahora, transformando y transfigurando la realidad de pecado y muerte en signos de vida. Pero este reino pasa por la cruz, es un reino pascual. Es el grano de trigo que muere para poder dar fruto $\left(J_{n} 12,24\right)$.

El concepto profético velerotestamentario del reino en el Nuevo Testamento se profundiza: Jesús es el paradigma simbólico de este reino, este reino no ś́lo es profético, sino pascual, pasa por la muerte para llegar a la resurrección. El signo de Jonás marca desde dentro el simbolismo del reino (Mt 12, 39-40).

Esto rompe todas las visiones interesadas y mundanas del reino, pero no lo deshistoriza ni lo espiritualiza: el reino de Dios comienza en la historia y por el misterio pascual llega a la escatología definitivamente. Lentamente, la realidad se va transfigurando hacia el reino por el misterio pascual. Pero el reino no es una institución, sino un horizonte simbólico que se va realizando, también simDigitalizado por Biblioteca "P. Florentino Idoate, S.J."

Universidad Centroamericana José Simeón Cañas 
bólicamente, en la historia.

Pero entonces, ¿qué relación existe entre este reino y la Iglesia?

\section{Reino de Dios e Iglesia a lo largo de la historia}

Jesús en su vida pública no sólo realiza gestos proféticos y simbólicos aislados. sino que reúne una comunidad de hombres y mujeres que lo siguen. La elección de los doce y de su comunidad tiene un valor simbólico: es un signo para Israel, como la semilla del nuevo Israel (Mc 3, 13-19). Los textos que se suelen usar para Cundamenlar la fundación de la Iglesia por el Jesús histórico (confesión de Pedro en Mateo 16, la institución de la eucaristía en la última cena, el primado de Pedro en Juan $21 . .$. ) no sólc han sido redactados a la luz de la pascua, sino que poseen una estructura produndamente etiológica y simbólica. También son simbólicos los relalos de la lanzada del costado en la cruz (Juan 19) y de pentecostés (Hechos 2), ligados al nacimiento de la Iglesia. La Iglesia nace en pascua, con la efusión del Espíritu.

¿Qué relación existe entre el reino que Jesús anunció y la Iglesia que ha surgido"? ¿Es aceplable la célebre alirmación de Loisy: "Jcsús predicó el reino y llegó la Iglesia"?

A lo largo de la hisloria de la Iglesia aparecen varias posturas acerca de la relación de Iglesia y reino, que muy sintéticamente podemos reducir a éstas cuatro.

La postura carismática (personal y espiritualista) parte de una lectura parcial de algunos textos (cl reino de Dios está en medio de ustedes, Lc 17, 21; mi reino no es de este mundo, Jn 18,36 ) y como consecuencia del retraso del reino, cuya venida se esperaba inminente, reducen el reino a sus aspectos más interiores y espirituales: el reino está dentro de nuestro corazón, en nuestra fe y adhesión a Jesús (Orígenes), en la experiencia personal del Espíritu (grupos espiritualistas medievales como Joaquín de Fiore, fraticelli, cátaros, valdenses, albigenses, algunos grupos protestantes y algunos movimientos espiritualistas de nuestros días). En consecuencia, se defiende un concepto de reino predominantemente interior, invisible, místico, poco eclesial y poco sensible a los problemas sociales e históricos del presente. El reino no es un símbolo de una plenitud utópica, sino una experiencia espiritual y personal de salvación.

La postura mesiánica (sociopolítica y militante) espera un reino material, presente en la tierra durante mil años (quiliasmo o milenarismo que interpreta literalmente Apocalipsis 20) o propugna una lucha violenta, pues el reino se debe implantar con la lucha armada (grupos revolucionarios de la izquierda luterana, como Thomas Müntzer, anabaptistas y movimientos revolucionarios modernos de inspiración marxista). Tenemos un reino sin Iglesia. La Iglesia o se convierte en plataforma militante para el advenimiento de un reino material o es 
un estorbo que se puede dejar de lado. En esta línea se situará todo el mundo ilustrado moderno, que reduce el reino a lo intramundano.

La postura eclesiocéntrica (intraeclesial) coloca el reino en la Iglesia, en la Iglesia constantiniana (Eusebio), en la Iglesia de cristiandad medieval (que identifica incorrectamente la Civitos Dei agustiniana con la Iglesia). Tenemos una reducción del reino a la Iglesia, una desescalologización de la Iglesia (lo cual provocará, como reacción, la doctrina luterana de los dos reinos). La Iglesia es una mera institución funcional, no un símbolo del reino. La Iglesia se ha apropiado todo el valor simbólico del reino en exclusividad. Fuera de la Iglesia no hay reino ni salvación.

Para la postura profética (simbólica) el reino de Dios es algo integral, personal y comunitario, espiritual y material, histórico y escatológico, tiene que comenzar a implantarse en la historia presente, comenzando por los que son víctimas de la justicia, los pobres y pequeños, anticipando así el reino escatológico futuro.

Recordemos aquí algunas de las características del símbolo: tiene sentido por sí mismo, es revelatorio y diáfano de la dimensión más profunda y sagrada de la realidad, es la única forma de acceder a lo otro, hace presente la otra mitad oculta, explica e implica, une a la comunidad y permite comunicar la tradición más íntima, a través de imágenes, mitos y ritos. Lo simbólico (que une e integra) se opone a lo diabólico (que divide y desintegra). Sólo desde la razón simbólica se podrá acceder al misterio profundo y tener una respuesta a la realidad negativa de la existencia humana, al misterio de iniquidad. 3 En este sentido, la Iglesia es símbolo del reino.

Este reino es el horizonte último y escatológico de la Iglesia, el reinado de Dios, que hunde sus raíces en ese misterio fontal y amoroso que llamamos Padre, en la novedad y presencia de Dios con nosotros, Emmanuel, que llamamos Jesús de Nazaret, y en el amor de Dios que se nos ha comunicado y nos da vida al que llamamos Espíritu. Pero este reino pasa por la cruz y la pascua. El reino es un símbolo no sólo profético, sino pascual. Este reino pasa por la cruz, porque se enfrenta a lo "diabólico" de nuestra historia y sólo por la fuerza del Esplritu puede avanzar.

De este reino horizonte último y simbólico, la Iglesia es a su vez un símbolo privilegiado, un símbolo no sólo profético, sino pascual del reino.

Esta última visión recoge lo positivo de los autores personalistas (como Orí-

3. Para una mayor explicación del símbolo remito a mi estudio "Una teología más simbólica y popular". Revista Latinoamericana de Teología 8 (1986), publicado luego en el libro Parábolas de la mina y el lago, Salamanca, 1990, pp. 117-148; para el tema de la razón simbólica puede verse mi libro Creo en el Espírifu Santo. Pneumatologia narrativa, Santander, 1994. 
genes), de los milenaristas (como Ireneo, que hablan de la dimensión material del reino), de grupos religiosos y laicales revolucionarios, antiguos y modernos, empeñados en transformar la sociedad de modo diverso (movimientos sociales y liberadores). Esta línea es la de la doctrina social de la Iglesia y la perspectiva abierta por el Vaticano II: la Iglesia es un sacramento (LG 1,9, 48..), "el germen y el principio de este reino" (LG 5).

Ya no se puede repetir el extra ecclesiam nulla salus, pues el reino es más amplio que la Iglesia y el reino no se identifica con la Iglesia, ni ésta posee el reino de forma exclusiva. El horizonte utópico simbólico propuesto por Jesús, es mayor que la Iglesia. El Espíritu actúa en la creación y en la historia y va fermentando la humanidad hacia el reino. La Iglesia concentra de forma simbólica y revelatoria lo que el Espiritu ha realizado en la historia de salvación, más allá de la historia olicial de Israel y de la Iglesia.

Pero este reino de Dios tendría el riesgo de esfumarse en una utopía sin mordiente o de convertirse en una simple ideología anónima, si no tuviese un lugar concreto de referencia. Este espacio simbólico, que en el Antiguo Testamento fue el pueblo de Israel, ahora es la Iglesia: ella es la que hace memoria de Jesús, de su misterio pascual, verdadera matriz simbólica y piedra angular no sólo de la Iglesia, sino del mismo reino. El mismo Espíritu que actúa en la creación y en la historia es el que hace nacer la Iglesia en la pascua.

La Iglesia sigue siendo símbolo de esie reino universal de Dios. Esta postura reconoce la necesidad de conversión personal (aspecto positivo de la postura personalista) y de la presencia sacramental del reino en la Iglesia (aspecto positivo de la postura eclesiocéntrica), pero ve necesario hacer presente el reino en la historia, sin reducir el reino a lo intramundano ni aceptar la violencia como método. Esta última postura es la que en América Latina se ha abierto paso en estos años a nivel eclesial, en las asambleas de Medellín, Puebla y Santo Domingo, en la praxis de muchos cristianos y en una reflexión teológica liberadora.

Todas las posturas no simbólico-proféticas del reino en relación con la Iglesia pecan del mismo defecto: reduccionismo a un aspecto parcial, apropiación interesada, institucionalización parcializada, visión unilateral y unidimensional del reino, división "diabólica". Hay como un deseo de aprovecharse del capital simbólico del reino, pero al servicio de intereses de grupo, aunque sea un grupo religioso.

El reino es visto desde la razón ilustrada o práctica como una institución, no como horizonte simbólico y matriz utópica. Y, consiguientemente, Ia Iglesia se reduce a una institución funcional: para la salvación personal (postura carismáticoindividualista de derechas) o para el progreso social (postura mesiánica de izquierdas).

La concepción de la Iglesia como simple institución funcional, que hemos 
descrito al comienzo de este artículo, nace de haber perdido de vista el horizonte simbólico y escatológico del reino. La Iglesia, para esta concepción tcológica, es ya el reino existente en la tierra y el clero es quien poseee las llaves de este reino y goza ya de los atributos escalológicos del reino.

Esta postura funcionalista de la Iglesia produce dos tipos de reacciones: la mística carismática, que intenta recuperar el reino por la vía de la experiencia interior mística, muchas veces al margen de la Iglesia, y la militante mesiánica, que busca la instauración ética del reino en la hisloria, pero prescindiendo de la Iglesia y del paradigma pascual de Jesús. Ambas reacciones reducen el símbolo a una dimensión espiritual o socio-política.

Se producen reacciones semejantes a las del Antiguo Testamento frente al reino de Dios: fariseos y esenios, por el lado espiritualista, zelotes y sadticeos, por el socio-político.

Habría, pues, un doble riesgo para los cristianos: el concebir una Iglesia institución funcional y práctica, pero poco simbólica y sin referencia al reino de Dios, y el tender a un reino concebido como una gran utopía, con gran carga simbólica, pero al margen de la Iglesia.

Por ello, es necesario al llegar aquí, plantear bien la relación Iglesia-reino.

Un reino sin Iglesia se esfuma y se diluye (cristianos por el reino, pero sin Iglesia; "Jesús sí, Iglesia no", "todas las religiones son iguales"). Una Iglesia sin reino se convierte en una mera institución religiosa, en una secta, que se asfixia por falta de horizontes escatológicos (eclesiocentrismo).

La Iglesia no se puede identificar con el reino ni es el único símbolo profético del reino en la historia. El Espíritu sopla donde quiere y como quiere, el Espíritu es libre (2 Cor 3, 17). En la Iglesia está el Espíritu, pero hay lugares donde el Espíritu actúa y la Iglesia no está presente ni tal vez nunca llegará a estar.

Una Iglesia identificada con el reino es incapaz de ver las semillas del reino en la historia, las culturas, las religiones, los signos de los tiempos. Pero defender que lo importante es el reino y creer que la Iglesia es una elapa ya superada, significaría perder la identidad cristiana y no despertar el plan de salvación de Dios, cuyo centro es Cristo Jesús, cuyo sacramento visible y comunitario es la Iglesia.

En el fondo, nos hallamos ante la difícil tarea de unir Jesús y Espíritu, cristología y pneumatología.

Una cristología sin Espíritu se convierte en un moralismo voluntarista, en un mesianismo más, que busca imilar el ejemplo heroico de Jesús, pero que puede desembocar en un fracaso total. La eclesiología sin pneumatología reduce la Iglesia a una simple organización de propaganda mesiánica. 
Una pneumatología sin Cristo nos lleva a un mar sin fondo de proyectos e ideologías: ¿de qué espíritu hablamos?, ¿de un espíritu cósmico, del de Hegel, del de Marx, del del neoliberalismo, del de la New Age, de un espíitu demoníaco? ¿O hablamos del Espíritu Santo, bajo cuya fuerza amorosa nace Jesús, actúa Jesús, muere y resucita Jesús, y camina hacia la escatología?

Un Jesús sin Espíritu lleva a una Iglesia sin reino. Un Espiritu sin Jesús nos lleva a un reino sin Iglesia.

Como repite Y. Congar de forma axiomática, toda pneumatologla es cristología y viceversa. S6́lo una correcta articulación de cristología y pneumatología nos permite concebir a la Iglesia como símbolo pascual del rcino.

Sin esta referencia simbólica, la Iglesia se agota en lo intraeclesial y en una eclesiología cristomonística. Y sin referencia a la Iglesia, el reino corre el riesgo de reducirse a una ideología, mística o violenta.

Dicho de otro modo, el reino es la expresión simbólica del proyecto trinitario de Dios en el mundo, que tiene en la Iglesia su centro sacramental. Despojar al reino de esta dimensión trinitaria, el misterio de comunicación del Padre, por el Hijo, en el Espíritu, es mutilar el reino y empobrecer la Iglesia. Cristología y pneumatología sólo alcanzan su sentido desde la visión trinitaria: son las dos manos del Padre, en expresión de Ireneo.

\section{Hacia una eclesiología desde la razón simbólica}

Intentemos ahora releer la eclesiología desde esta visión simbólica de la Iglesia y del reino.

Las imágenes brblicas del pueblo de Dios en el Antiguo Testamento y de la Iglesia en el Nuevo Testamento son simbólicas: ciudad colocada en lo alto, árbol frondoso, cuerpo, templo, rebaño, vid, pueblo, casa, edificación, luz, sal, familia, madre, esposa, Jerusalén...

El Vaticano II aplica a la Iglesia algunas imágenes que originariamente se refieren al reino (LG 5-6): semilla, luz, redil, agriculturas de Dios, vid, edificación de Dios, templo, ciudad santa, Jerusalén, esposa. Indirectamente aparece tanto el carácter simbólico del reino como de la Iglesia y su mutua implicación: la Iglesia es sacramento (LG $1 ; 9 ; 48$ ) y germen del reino (LG 5).

Tanto Israel como la Iglesia revisten, pues, un sentido simbólico: son una señal, un signo para los naciones, para el mundo. El deseo de Jesús, al formar una comunidad y elegir a los doce, no es la creación de una nueva organización religiosa, sino que tiene un profundo significado simbólico: reunir a los hijos de Dios dispersos (Jn 11, 51-52).

La tradición eclesial claramente afirma esta dimensión simbólica de la Iglesia y dentro de ella de la jerarquía. Agustín es claro: 
El Señor Jesús, antes de su pasión, como sabéis, eligió a sus discipulos, que dio el nombre de apóstoles. Entre ellos Pedro fue el único que representó la totalidad de la Iglesia casi en todas partes. Por ello, en cuanto él solo representaba en su persona a la totalidad de la Iglesia, pudo escuchar estas palabras: "Te daré las llaves del réino de los cielos", porque estas llaves las recibió no un hombre único, sino la Iglesia única. De ahí la excelencia de la persona de Pedro, en cuanto él representaba la universalidad y la unidad de la Iglesia, cuando le dijo "yo te entrego" tratándose de algo que ha entregado a todos.

Pues para que sepáis que la Iglesia ha recibido las llaves del reino de los cielos, escuchad lo que el Señor dice en otro lugar a todos sus apóstoles: Recibid el Espíritu Santo. Y a continuación: A quienes les perdonéis los pecados les queden perdonados; a quienes se los retengáis les quedan retenidos.

En este mismo sentido, el Señor después de su resurrección, encomendó también a Pedro sus ovejas para que las apacentara. No es que él fuera el único de los discípulos que tuviera el encargado de apacentar las ovejas del Señor; es que Cristo, por el hecho de referirse a uno solo, quiso significar con ello la unidad de la Iglesia; y si se dirige a Pedro con preferencia a los dernás es porque Pedro es el primero entre los apóstoles. 4

De esta consideración simbólica de la jerarquía se desprende que los obispos y sacerdotes no constituyen una casla aparte, sino que son sus representantes simbólicos al servicio del pueblo y para mantenerlo unido en la comunión. Su designación requiere una ordenación sacramental, pues es algo que va más allá de toda delegación administrativa o representación funcional, sindical o política. Pero actúan no sólo representando a Cristo (in persona Christi), sino también en nombre de todo el pueblo de Dios (nomine totius populi) (LG 10), dentro de la comunidad eclesial. Por esto, la tradición eclesial da al pueblo un papel activo en la elección y remoción de sus pastores.

Paradójicamente, una visión funcional de la Iglesia convierte a las funciones o ministerios en estados y grados de perfección ontológica, mientras que una visión simbólica de la Iglesia devuelve a los ministerios su carácter funcional de pastores de la comunidad y de ministerios de la Palabra (PO 4), al servicio de una misión que no es propia, sino del Espíritu.

Una actitud de descentralización eclesial, de recepción, de amplia consulta, de confianza mutua se impone para que los pastores puedan cumplir su misión. Hay que evitar la impresión de que ellos son los dueños y propietarios de la Iglesia del Señor o del reino de Dios. La imagen del buen pastor que da la vida por sus ovejas y que desea que todos tengan vida en abundancia, continúa siendo actual y válida (PO 13).

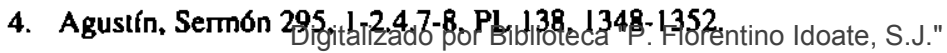


Cuando se pierde la razón simbólica se cae en la razón cuantitativa del más o menos, del arriba y abajo, del todo y nada.

Desde la visión simbólica, el magisterio expresa autoritativamente el sentido de fe de toda la comunidad, pues el sentido de la fe es común a todo el pueblo de Dios, la infalibilidad pertenece a todos los fieles, que han recibido la unción del Espíritu (1 Jn 2, 20.27; cf. LG 12) y la misma infalibilidad del magisterio del romano pontífice se sitúa dentro de la infalibilidad que Cristo quiso que gozase toda su Iglesia (DS 3074).

Cuando se olvida la dimensión simbólica, el ministerio no simboliza, sino que sustituye al misterio. Entonces desaparecen el sensus fidelium (LG 12), la opinión pública en la Iglesia (LG 37), la complementariedad de los carismas, el magisterio profético. Cualquier actividad que no nazca de arriba es considerada paralela, y sospechosa. La dimensión bautismal de la fe y el sacerdocio de los fieles se oscurecen en favor de un sacerdocio ministerial, en lugar de verlos a los dos como formas diversas de participar del único sacerdocio de Cristo (LG 10).

En una visión simbólica, los mismos sacramentos dejan de ser meros instrumentos eficaces de gracia para ser celebraciones simbólicas y litúrgicas del reino en la Iglesia, símbolos proféticos del reino en la Iglesia, que prolongan las acciones proféticas de Jesús con su pueblo (ôt), celebrados en la comunidad eclesial, momentos simbólicos y celebrativos de la Iglesia, con una eficacia que proviene de la misma presencia del Espíritu del Señor en la Iglesia. Estos símbolos proféticos son pascuales.

La eucaristía, cuerpo místico y simbólico de Cristo, es el centro de la comunión eclesial, fuente y cumbre de la vida cristiana (LG 11), carne de Cristo y de la Iglesia. La eucaristía participa también de la dimensión simbólica del reino, anticipa el banquete del reino, lanza a la construcción del reino en la sociedad, para que todos puedan sentarse fraternalmente en la mesa de la creación y en el banquete de la historia. Por esto, el fruto último de la eucaristía no es construir la comunidad eclesial, sino el reino de Dios en la historia.

En esta perspectiva, la presencia real adquiere su fundamentación teológica más profunda, que se oscurece por vez primera en el momento en que, en torno al año 1000 , se opera el cambio del símbolo a la dialéctica (en expresión de $\mathrm{H}$. de Lubac) y se pasa de la razón simbolica a la instrumental. Desde la razón simbolica, la Iglesia vuelve a ser, como en el primer milenio, el cuerpo verdadero y real de Cristo, en cuyo centro está la eucaristía.

Por esto mismo, no basta la validez de las palabras consacratorias para que tengamos una ecucaristía que simbolice el reino en la Iglesia. Los problemas de la validez sacramental sólo pueden resolverse correctamente desde el ámbito del simbolismo eclesial y del reino.

Consiguientemente, los sacramentos han de ser vistos no sólo en su dimen- 
sión personal y eclesial, sino lambién social y escatológica, como símbolos del reino que deben anticipar en la historia: al servicio de la vida nueva (bautismo), del derecho y la justicia (conlirmación), de quitar el pecado del mundo (penitencia), del amor interpersonal y sexual en una nueva sociedad (matrimonio), de la salud (unción), de la misma comunidad del reino (ministerio ordenado). 5

La vida religiosa ha sido vista tradicionaimente como un símbolo profético y escatológico del reino, que no forma parte de la estructura jerárquica de la Iglesia, pero sí de su vida y sanlidad (LG 44) y se han considerado la comunidad y los votos como signos y símbolos de este proyecto de vida evangélica.

La significatividad del ser religioso no quiere decir que su presencia no sea eficaz, sino que es la elicacia que nace de su ser simbólico y profético, no al margen o en contra de él: el hacer nace del ser. Cuando mayor sea su simbolismo profético, mayor será su eficacia evangélica. Esto permite respetar la pluralidad carismática (LG 46), dar respuesta a los signos de los tiempos y presentar signos prófeticos y escatológicos del reino en una situación de anti-reino.

Tampoco significa que la vida religiosa sea la única instancia profética y escatológica de la Iglesia, sino que la vida religiosa simboliza proféticamente la tensión de toda la Iglesia hacia la escatología. La terminología del estado de perfección cede así a una visión más carismática y simbólica de la vida religiosa.

No hay incompatibilidad entre vida religiosa y ministerio sacerdotal, pero no se puede considerar a la vida religiosa laical como inferior a la clerical, ni a la vida religiosa femenina inferior a la masculina porque no poseen el sacerdocio.

El matrimonio, a pesar de todas las tentaciones reduccionistas y utilitarias, se ha considerado siempre en la tradición de la Iglesia desde la razón simbólica: un símbolo del amor esponsalicio entre Dios y su pueblo, entre Jesús y su Iglesia (Ef 5), símbolo de la nueva humanidad (Apoc 21). Y el amor implica gratuidad, relación interpersonal, entrega vital, goce no sólo espiritual, sino placer corporal y sexual. Hablar de procreación sin antes haber establecido la dimensión de comunidad amorosa de los cónyuges es instrumentalizar y pervertir el sentido del matrimonio. Reducir la sexualidad a la procreación es desconocer no sólo el rico dinarnismo de la naturaleza, sino la dinámica fecunda del amor. El matrimonio es definido por el Vaticano II como "íntima comunidad conyugal de vida y amor" (GS 48).

La vida matrimonial no puede ser considerada como un estado inferior a la virginidad, como el mismo Juan Pablo II ha reconocido: "Las palabras de Cristo citadas por Mateo 19, 11-12, así como las palabras de Pablo en la Primera Carta

5. He desarrollado esta perspectiva en el capílulo de sacramentos en Mysterium liberarionis II, Madrid 1990, pp. 267-294. 
a los Corintios, capítulo 7, no dan motivo para sostener ni la inferioridad del matrimonio, ni la superioridad de la virginidad o del celibato"6.

El laicado no se puede seguir definiendo de forma negativa, como cristianos que no son sacerdotes ni religiosos (LG 31). Son un símbolo de la dimensión secular de toda la Iglesia, como una concentración simbólica de la presencia de la Iglesia en el mundo. El laicado no sería ya el sector cristiano reducido esclusivamente a lo secular, mientras que el monopolio de la vida intraeclesial estaría en manos del clérigo: ni el sacerdote está al margen del mundo secular, ni el laico fuera del ámbilo intraeclesial.

Más aún, en una eclesiología simbólica, la misma terminología de "laico" y "teología del laicado" debería desaparecer y hablarse simplemente del pueblo de Dios, de los bautizados. La palabra "laico" es correlativa a "clero", expresiones dialéclicas de una eclesiología funcional de cristiandad, donde unos dirigen y enseñan y otros simplemente obedecen y aprenden.

Por todo ello, el Vaticano II al definir a la Iglesia desde la razón simbólica como sacramento (LG 1, 9, 48..), vuelve a la tradición más profunda de la teología, aunque luego presente una definición de sacramento excesivamente escolústica: "signo e instrumento" (LG 1). Esta definición de sacramento no expresa toda la riqueza simbólica del ser sacramental de la Iglesia. La eficacia del sacramento es simbólica, nace de la presencia misma de la realidad escatológica del reino en la. Iglesia, de la fuerza del Espíritu en la comunidad de Jesús en la historia.

El reino es un horizonte simbólico y la Iglesia un símbolo profético y pascual del reino. Y todo ello por la fuerza del Espíritu, que es el que hace surgir la Iglesia de Jesús al servicio del reino.

A nadie se le oculta que esta visión simbólica, cristológica, pneumatológica y trinitaria de la Iglesia tiene consecuencias para el diálogo ecuménico con las Iglesias cristianas de la ortodoxia y de la reforma y con las religiones de la humanidad.

\section{Algunas conclusiones: la levadura en la masa}

Saquemos ya algunas conclusiones que resuman todo el camino recorrido.

La expresión "reino de Dios" es el símbolo de una realidad profunda, última y misteriosa que constituye como el horizonte utópico de toda la historia de salvación: es el proyecto trinitario de Dios, radicado en el amor misericordioso y salvifico del Padre, que se realiza a través de las misiones históricas del Hijo y del Espíritu . Desde aquí aparece con claridad que el reino es gracia, don de

6. Juan Pablo II, Discurso a los esposos del 14 de abril de 1987. 
Dios, que alcanzará su plenitud integral en la escatología y que las realizaciones del reino en la historia son necesarias (instancia escatológica), aunque siempre sean parciales (reserva escatológica).

La Iglesia, sacramento y germen del reino, ha de procurar ser un símbolo lo más trasparente y eficaz posible del reino. Para ello cuenta con el don del Espíritu del Señor que la dinamiza hacia la misión de realizar el reino en el amor, cuyo símbolo mayor es el martirio, testimonio de la entrega evangélica. La fuerza simbólica del reino se hace presente en la Iglesia de forma irrevocable. La Iglesia no es la mera prolongación de la sinagoga de Israel.

El reino tiene una dimensión pascual que la Iglesia simboliza: Ia Iglesia hace memoria continua del misterio de la vida, muerte y resurrección de Jesús de Nazaret, en su liturgia y en su praxis cristiana. Sin pascua, la Iglesia sería un símbolo desprovisto de identidad cristiana.

Dentro de esta simbolización del reino, aparece la fuerza de la dimensión comunitaria: si el reino es comunión, koinonía, la Iglesia es signo del reino, comunidad de amor fraterno y de solidaridad humana, cuyo sacramento es la eucaristía. Antes de actuar, la Iglesia es ya símbolo del reino por el mismo hecho de ser "una muchedumbre reunida por la unidad del Padre, del Hijo y del Espíritu Santo" (LG 4).

El reino de Dios no es meramente interior ni exterior, sino integral, profético y parcial hacia los pobres: la Iglesia deberá ser esencialmente una Iglesia universal, pero sobre todo Iglesia de los pobres, que opta por los pobres y tiene en ellos su centro vital y simbólico. La opción por los pobres es una opción simbólica. ${ }^{7}$

Las dificultades de la Iglesia en su misión profética, las persecuciones y cruces, forman parte de esta dimensión pascual del reino que la Iglesia simboliza: la Iglesia prosigue el camino de Jesús de luchar contra el anti-reino, en medio de persecuciones y sombras (LG 8), cargando con el pecado del mundo, como el Cordero de Dios (Jn 1,29).

Los diversos carismas y ministerios de la Iglesia participan de la dimensión simbólica del reino en la Iglesia, de su profetismo pascual y esto ha de aparecer en su recíproca colaboración, sin caer en monopolios exclusivos de unos u otros, ni en una mera organización funcional, pues son dones del Espíritu para el bien de la Iglesia y del reino.

7. Al decir simbólica no se quiere decir que no sea real. Es precisamente una visión no simbólica sino lógica de la Iglesia la que ha llevado a precisar esta opción por los pobres diciendo que es preferencial, no excluyente. Resulta curioso y significaivo que sólo en el caso de los pobres se haya querido matizar, cuando no se hace ante otras afirmaciones, también simbólicas, de la lglesia. 
Pero la Iglesia no es el reino de Dios, sino un símbolo histórico, sacrament del reino, y siempre será una aproximación parcial e inadecuada del reino, qu necesita del diálogo con otras formas de acción del Espíritu en la historia, dond el reino está presente: religiones, culturas, signos de los tiempos (GS 4, 11, 44) El símbolo significa y reúne lo disperso. Pero lo definitivo (escatológico) no e la Iglesia, sino el reino.

Las limitaciones de la Iglesia, el error, el pecado, el espesor y la opacida humana se inscriben en esta radical desproporción entre el reino y la Iglesic entre el símbolo y el significado. Esto no es una excusa para la pereza, sino un razón de esperanza que nos evite el escándalo farisaico y el desengaño infanli Toda identificación entre la Iglesia y el reino a la larga produce traumas desencantos.

Sólo en la plenitud escatológica del reino aparecerá el misterio oculto de 1 acción del Espíritu en la Iglesia y en la historia. Mientras tanto, vivimos en fe en esperanza, sabiendo que el Espíritu del Señor camina con su pueblo y ، reino avanza lentamente, pero con fuerza, como el fermento penetra la masa.

La parábola de la mujer que mezcla un poco de levadura en medio de masa hasta que todo fermente (Mt 13,33) puede ser un símbolo conclusivo de relación Iglesia y reino. La mujer simboliza a la Iglesia comunidad, empeñac en fermentar la masa del mundo con la levadura del evangelio. No se encien en sí misma, despreciando a la masa, pensando que ella es ya el reino, ni dest conquistar la masa para ejercer su dominio en el mundo.

Se trata de iniciar un proceso de fermentación y transfiguración del mund un proceso lento y doloroso, pues supone una cierta muerte y ocultamiento de levadura, mezclada en la masa, al servicio del mundo. Pero es un proceso efica porque cuenta con la presencia profética del Espíritu que da vida a la comunid: de Jesús, a sus gestos de palabra, liturgia y acción social, y actualiza en historia el misterio pascual, el paso de la muerte a la vida.

Una visión meramente racionalizada y computarizada de la realidad nun podrá comprender lo que está sucediendo en la historia, ni por qué, ni para qu Sólo la mujer-Iglesia, que ha escuchado y vivido la palabra del Señor y se sa poseedora de su Espíritu, cree que está anticipando proféticamente el reino que los pobres han de ser sus primeros destinatarios.

Una visión meramente militante del reino y de la Iglesia se desespera ante lentitud del proceso y desea forzar los límites del tiempo, violentar el resulta final. 


\section{LA IGLESIA, SIMBolo PROFETICo PASCUAL}

personal y estruclural, los retrocesos continuos, la dureza del entrentbimionto con el poder del mal.

Esta parábola, que seguramente tiene como trasfondo la experiencia de Jesús de ver amasar el pan a las mujeres de Nazaret y su misma madre María, sc prolonga en la acción de tantas mujeres de hoy que, callada pero eficazmente, van amasando el pan para los pobres, pan para la vida de la humanidad.

Un símbolo que anticipa ya el pan de vida y el banquete del reino. El simbolismo de la Iglesia como profecía pascual del reino halla su expresión sacramental más fuerte en la eucaristía: el Señor muerto y resucitado es el fermento, que por la fuerza de su Espíritu, don pascual, va transfigurando la masa del mundo en su reino. El banquete del reino se anticipa en la fracción del pan, como profecía utópica del reino y se convierte en exigencia eclesial de vivir lo que se celebra.

En el momento aclual de la historia, cuando han cardo ideologías y sospechamos de los grandes relatos, cuando no tenemos a mano proyectos alternativos al sistema del mercado neoliberal, cuando no podemos destruir frontalmente el sistema dominante, ni tampoco huir fuera de él, la parábola de la levadura recobra especial actualidad: estar presentes como Iglesia en la historia, para transformarla desde dentro con la levadura del evangelio hacia el reino. Como hizo María, por la fuerza del Espíritu. 